\title{
EL CUERPO HUMANO COMO SÍMBOLO EN EL JARDÍN DE LAS DELICIAS: EL TRÍPTICO DE EL BOSCO Y LA PELÍCULA DE CARLOS SAURA
}

\section{Introducción}

Cuando en España se menciona El jardín de las delicias, lo primero que a uno le viene a la mente es el tríptico que pintó el holandés Hieronymus Bosch, más conocido como El Bosco, en el siglo XVI. Pero además de este cuadro, que actualmente se encuentra en el Museo del Prado de Madrid, hay otras dos obras con el mismo título en este país: una es la pieza literaria de Francisco Ayala titulada El jardín de las delicias. El tiempo y yo y la otra, una película del realizador Carlos Saura, que es en la que voy a centrar precisamente mi interés a fin de estudiar las conexiones que existen entre ella y el cuadro pintado por El Bosco. ${ }^{1}$

Aunque a la hora de hablar de una posible relación, Saura admitió que en su "cuadro fímico" existía una referencia explícita al pictórico, el cineasta no llegó a explicar a fondo esta cuestión, o al menos eso es lo que se desprende de una entrevista concedida a E. Brasó (1974:288):

Yo creo que el título de El jardín de las delicias se corresponde con lo que narra, es coherente con la película. Pero no tiene una relación directa con el cuadro de $\mathrm{El}$ Bosco. La hay en cuanto que el cuadro de El Jardín de las delicias me sugiere algo del cuadro que he hecho... No sé, en cierta forma esta idea mía de construir un retablo grotesco... Pero el cuadro, aunque sí es un retablo grotesco, está llevado al paroxismo simbólico, donde ya los seres dejan de ser seres y se convierten en extraños animales. En el fondo, sí, qué duda cabe de que hay una influencia; muy lejana, pero influencia. Y en ese sentido el título es explícito.

Años más tarde, Saura daba la impresión de haber reflexionado más profundamente sobre esta cuestión, y en otra entrevista concedida a B. Cohn (1977:31) explicaba así el porqué del título:

\footnotetext{
${ }^{1}$ Como dato anecdótico, una vez se empezó a exhibir la película, cuenta Saura que recibió una carta del dramaturgo Fernando Arrabal en la que éste le acusaba de haber plagiado una obra suya de teatro que iba a estrenar también con el mismo título. Ante esto el cineasta le respondió que, por si lo había olvidado, El jardín de las delicias también era el nombre de un cuadro famoso (en M. Hidalgo, 1981:82).
} 
Primero, porque me gusta mucho el cuadro. Luego, porque España es un poco un jardín de las delicias lleno de pequeños monstruos. He pensado que en el jardín se puede hacer de todo, todo puede ocurrir. ${ }^{2}$

En estas explicaciones Saura hablaba de "retablo grotesco", "paroxismo simbólico", "seres convertidos en animales", "monstruos", "jardines"... admitiendo que todos estos elementos estaban presentes de un modo u otro en su película. Sin embargo, lo que el cineasta no logró ver es el significado y la función que desempeñaban en ella, ya que sólo un análisis detallado de la simbología que encierran ambas obras puede ayudarnos a establecer conexiones a un nivel más profundo.

Ese enfoque simbólico que queremos darle a este estudio nos obliga, en primer lugar, a establecer una definición satisfactoria y lo menos restrictiva posible de lo que se entiende por símbolo. Partiremos para ello del concepto "barthiano", que viene a decir que un objeto se convierte en símbolo cuando adquiere, mediante su convención y uso, un significado que lo capacita para significar otra cosa. ${ }^{3}$ Nuestro objeto de estudio girará en torno al cuerpo humano, al que elevaremos a la categoría de símbolo a fin de ver adónde nos conduce su presencia y tratamiento tanto en el cuadro de El Bosco como en la película de Saura. A este respecto me parece adecuado mencionar aquí lo que dice Peradejordi (1991:7) en su libro titulado precisamente El cuerpo humano:

Un símbolo es un estímulo capaz de trasladar a quien lo recibe del plano de lo fenomenológico y existencial al de lo absoluto e inamovible. El símbolo abre el campo de la conciencia haciendo percibir todos los aspectos de la realidad: lo sensible y lo velado, lo manifiesto y lo oculto, lo consciente y lo inconsciente.

El símbolo actúa abriendo el consciente más inmediato y, al mismo tiempo, haciendo emerger hasta la superficie de la conciencia elementos inconscientes por asociación y encadenamiento espontáneo de emociones, imágenes, recuerdos y pulsaciones, concatenando así una reserva de significados.

$\mathrm{Al}$ despertar tanto nuestro consciente como nuestro inconsciente, el símbolo nos revela a nosotros mismos, poniendo a cada uno frente a su "otro".

\section{El jardín de las delicias de Hieronymus Bosch}

Hieronymus Bosch, conocido como "el pintor de los martirios infernales", fue un artista que se destacó por su actitud burlesca y moralista muy cercana a la Edad Media, tal y como se refleja en sus pinturas alegórico-religiosas y en sus temas satíricos tomados de la vida cotidiana.

\footnotetext{
${ }^{2}$ La cita ha sido traducida por la autora de este artículo.

${ }^{3}$ Para más información a este respecto consultar el libro de John Fiske, Introduction to Communication Studies, 2nd edition, London: Routledge, 1996, pp. 85-92.
} 
El jardin de las delicias concretamente nos ofrece un panorama de figuras que parecen haber sido dotadas de movimiento y donde los límites entre el reino vegetal y animal, la vida y la muerte, lo real lo irreal, dan la impresión de haber desaparecido.

En la composición del cuadro cabe destacar, en primer lugar, la importancia del número tres, que resuelve el conflicto planteado por el dos. El tríptico representa los tres niveles cósmicos, el mundo inferior, el mundo terrenal y el mundo superior, distribuidos de la siguiente manera: A la derecha, la creación; a la izquierda, el infierno, donde un curioso demonio defeca a los pecadores condenados al fuego eterno; y en el centro, parte principal del lienzo donde vemos numerosos cuerpos de hombres y mujeres desnudos y en diversas posturas eróticas, algunos de ellos en posición invertida o metamorfoseados en pájaros o peces, aparece representada la apoteosis de la sexualidad pecaminosa como antecámara del infierno. Esta antecámara es una morada ambivalente, pues lo mismo conduce a la salvación que a la condenación, al mundo superior o al inferior, representados como paraíso o infierno en las alas del tríptico.

No cabe duda de que el cuadro encierra una gran complejidad y por eso ha dado lugar a múltiples interpretaciones, tanto desde el punto de vista de la simbología tradicional, que el autor conocía muy bien, como del psicoanálisis.

En lo que respecta a la simbología tradicional, en El jardín de las delicias se observan ciertos símbolos tomados del repertorio gótico presentes a su vez en el esoterismo alquímico y en la cabalística, que convergen en los grandes mitos universales. Entre ellos están el jardín, y asociado a su representación el paraíso terrestre y el cosmos, tal y como señala José Luis Morales y Marín (1984:257):

De origen hebreo, el término paraíso equivale a jardín reservado... por lo que los padres de la Iglesia lo llaman sucesivamente "vergel eterno, lugar de delicias donde las flores se abren constantemente".

También están asociados al paraíso terrestre dos árboles centrales: el árbol de la vida y el árbol de la cienca del bien y del mal, que opone una dualidad al primero. Este último es el árbol de la caída de Adán porque tiene su origen en la experiencia de que el conocimiento conduce al pecado y por lo tanto, significa la experiencia de lo negativo en el mundo y en el hombre, que debe experimentar en sí mismo los sufrimientos de la muerte y la resurrección iniciáticas, equivaliendo ese segundo nacimiento al verdadero conocimiento (J. Chevalier y A. Gheerbrant, 1986:119).

Por último, la fuente de la vida, que se halla en el centro del paraíso terrenal del cuadro, es también muy importante en la simbología esotérica y un tema alquimista que nos remite nuevamente a la idea de la renovación inagotable, del árbol con brotes y de la resurrección, porque la alquimia pide al hombre que sea capaz de acceder a un nivel espiritual que le convertirá en dueño de la materia.

La presencia de estos y otros muchos símbolos nos llevan a pensar que en El jardín de las delicias El Bosco quiso representar, de acuerdo con la moral cristiana, cómo los placeres 
ciegan a la humanidad, que corre hacia su perdición. En ese sentido el cuadro refleja las partes constitutivas de la naturaleza humana que el hombre no consigue vencer ya que confunde el placer con la felicidad y esto le hace olvidar su salvación espiritual. ${ }^{4}$

Lo que el ser humano busca es liberarse del peso de su ambivalencia instintiva expresando su angustia e intentando superarla en medio de la gran oscuridad, pero el vértigo que experimenta con ello le hace retornar incesantemente sobre las imágenes que suscita y que le fascinan. La pintura recoge de este modo los principios de la filosofía presocrática de los sofistas, Pitágoras y Empédocles, plasmándolos a través de una concepción cristiana donde se presenta la dicotomía entre el bien y el mal y donde se mezclan la lógica y el absurdo, aunque se vislumbra la ordenación sistemática de un caos en el cual ya no tienen vigencia ni las leyes morales ni las sociológicas, ni siquiera las leyes históricas por las que se guía nuestra conducta. Como deduce Gauffreteau (1967:240):

Bosch halló un morboso placer en ir descomponiendo el mundo como una maquinaria pues, al hacerlo, aparte de saciar su inmensa facultad de imaginar y de recrear por la imagen visual, exponía su idea del mundo, su concepción de una realidad fatalmente escindida y destinada a una progresión cuantitativa que Plotino condenó ya en sí misma, pero que imaginó apta para una reversión gigantesca hacia la fuente originaria y primordial.

En lo que respecta a las reflexiones psicoanalíticas de las que también ha sido objeto $E l$ jardin de las delicias, hay que decir que si bien parten de postulaciones y teorías diferentes, las conclusiones a las que llegan se aproximan considerablemente a las interpretaciones tradicionales. A la luz de las teorías de Jung y Freud por ejemplo, los desnudos pintados por El Bosco no tienen nada de sana sensualidad, sino que son descarnados y de una perversión altamente intelectual. De ello podría deducirse que su autor debió estar atrapado entre el horror y el deseo, entre el ascetismo y el libertinaje, pues la concatenación de los placeres de los sentidos que se observa en la pintura nos hace pensar en una gran represión sexual, en una crisis del individuo que lucha entre la austeridad y la tensión mística por un lado, y el placer de la carne y la libertad sexual por el otro. A este respecto me remito de nuevo a las reflexiones de Gauffreteau (1976:130):

Muchas veces, en el "jardín", los deseos insatisfechos intentan irrumpir en la conciencia, desde el insconsciente. El encuentro o, más bien, el choque de los instintos profundos con las prohibiciones forjadas por la educación familiar y por la sociedad, necesariamente habían de producir una angustia de conciencia que parece directamente ligada, en Bosch, al miedo al castigo. Sus terribles Infiernos lo confirman, así como muchos elementos

\footnotetext{
${ }^{4}$ No hay que olvidar que el cuadro es además contemporáneo a la época en que Erasmo escribió sus discursos, y es probable que El Bosco tratara con su pintura de reflejar la profunda crisis religiosa y moral que iba a provocar la separación del Norte de Europa.
} 
esparcidos por su obra y más o menos conducentes a la idea de la castración $[\ldots]$

Si intentamos esquematizar lo dicho más arriba, vemos que todo el cuadro aparece marcado por una tensión entre las dos partes constitutivas de la naturaleza humana, que a su vez se presentan asociadas a una serie de elementos:

$\begin{aligned} \text { MAL } & \text { BIEN } \\ \text { Cuerpo } & \text { Espíritu } \\ \text { Sexualidad } & \text { Misticismo } \\ \text { Instintos } & \text { Prohibición } \\ \text { Condena } & \text { Salvación } \\ \text { Descenso } & \text { Ascensión } \\ \text { Izquierda } & \text { Derecha } \\ \text { Árbol de la vida } & \text { Árbol de la ciencia } \\ \text { Muerte } & \text { Resurrección }\end{aligned}$

Estos pares dicotómicos también se encuentran presentes, como veremos, en El jardín de las delicias de Saura, y la forma en la que pasaré a demostrarlo es mediante un análisis pormenorizado de algunas de las secuencias más significativas del filme.

\section{El jardín de las delicias de Carlos Saura}

Por sus características generales, podríamos clasificar este Jardín de las delicias de drama psicológico: La película, que fue realizada en $1969,{ }^{5}$ cuenta la historia de Antonio Cano, un hombre de unos cuarenta años que tras sufrir un accidente de coche cuando iba con su amante, queda en un deplorable estado mental y físico, ya que ha perdido la memoria y debe estar en una silla de ruedas. Ante esta situación su familia, que pertenece a la alta burguesía madrileña católica y de derechas, intenta mediante una serie de representaciones y asociación de ideas, hechos y personas, que el enfermo recuerde su vida pasada y sobre todo, ciertos datos relacionados con el negocio familiar. Pero además de estas representaciones el propio Antonio, de forma mayormente involuntaria, va a experimentar en ocasiones un desdoblamiento que le hará ser protagonista de otro tipo de representaciones, en este caso subjetivas.

Las cuatro secuencias seleccionadas aquí corresponden precisamente a dos representaciones familiares organizadas por el padre de Antonio, y alternadas a ellas, dos representa-

${ }^{5}$ El jardín de las delicias, al igual que otras muchas películas de la época, tuvo problemas con la censura española siendo retenida durante siete meses por la Dirección General de Cine. Entre los motivos que en su momento fueron causa de problemas para su exhibición, se argumentaron los siguientes:

- Burla manifiesta hacia la acción de nuestro Ejército en cuanto a la última guerra española y desprecio hacia los principios del Movimiento Nacional.

- Presentación irreverente de las prácticas, creencias y ceremonias religiosas con una intención maligna que confina a la blasfemia (M. Oms, $1981: 141$ ). 
ciones subjetivas originadas por el protagonista. Para poder identificarlas, pasaré a denominarlas de la siguiente manera:

1. Secuencia de la iniciación

2. Secuencia de la caída

3. Secuencia de la Primera Comunión

4. Secuencia final

\section{Secuencia de iniciación}

La película comienza cuando la familia de Antonio hace una primera representación al enfermo, obligándole a remontarse a la edad de cinco años. Vemos cómo el protagonista es trasladado hasta el escenario que han montado todos los miembros de la casa: el padre, la esposa, los hijos, la enfermera, los sirvientes y una actriz profesional que sustituye a la madre, ya fallecida. En el escenario están el padre y la actriz/madre hablando de su hijo, que en ese momento deja de ser Antonio y pasa a ser "Antoñito". Al parecer, "Antoñito" es culpable de algo; ha sido malo y ha provocado el llanto de la madre que, mirándole, le llama "desalmado" y "carne de horca", términos que nos remiten a la idea de pecado y condena.

En la segunda parte de la representación se procede a la ejecución del castigo que impone el padre extendiendo su mano derecha y gritando: “ $¡ A$ la pocilga!”. Éste consiste concretamente en llevar a "Antoñito" a un cuarto oscuro de la casa en el que ellos han metido un cerdo (al parecer, cuando el protagonista era niño le sucedió algo parecido, causándole este incidente un fuerte trauma), para que "le coma las manitas y los piececitos".

Por último, una vez que el padre considera que "los símbolos han trabajado", "Antoñito" es sacado casi inconsciente del cuarto y llega el momento del perdón. Éste es llevado a cabo por la actriz/madre previa indicación del director de escena/padre y consiste en hacerle al "niño" la señal de la cruz en la frente, después de amonestarle con la siguiente recriminación: "Ya has visto lo que les pasa a los niños malos. Por esta vez te perdonamos. Hala, ahora a la cama, Antoñito".

En esta secuencia tiene un papel fundamental el anciano padre, en calidad de director de escena y suplente temporal de Antonio en el clan familiar, pues su figura nos hace encontrarnos ya ante la presencia de los tres estamentos en los que se funda la sociedad patriarcal: la nación, la familia y la religión, que aquí son inseparables y nos están remitiendo a la España franquista en la que se asienta toda la acción de la película.

Esto queda ilustrado en la secuencia cuando al enviar a su hijo "a la pocilga", el padre extiende su mano derecha; y más adelante, cuando la actriz/madre utiliza la "práctica curativa" de la religión a la hora del perdón.

Por otro lado, el padre está utilizando aquí de forma obvia y manipuladora el psicoanálisis, con el fin de hacer recordar un momento traumático de la vida de su hijo. Ese momento, según Freud, es el de la iniciación y está directamente relacionado con la figura de la madre, el complejo de Edipo y la incipiente sexualidad del niño. 
Entre los símbolos que el padre usa destaca el cerdo como el monstruo que va a mutilarle el cuerpo. En términos psicoanalíticos, el cerdo representa el miedo a la castración y a otro nivel, siguiendo la simbología tradicional, este animal está asociado a lo sucio, lo impuro, los bajos instintos y lo terrenal. Es, según Morales y Marín (1984:93), la alegoría de la gula como pecado capital:

El cerdo es la mutación de lo superior en lo inferior, del abismamiento amoral en lo perverso.También simboliza la voracidad y significa las tendencias oscuras sobre todas las formas de la ignorancia.

\section{Secuencia del jardín}

Tras ser enviado a la cama, el protagonista ha tenido una ensoñación en la que se ha imaginado en otra habitación y en otro tiempo, también de niño. En ella, ha recibido la visita de su sofisticada y sensual tía —otra figura sustitutoria de la madre-, que al despedirse de él le ha dado un beso de buenas noches en los labios. Ahora nos encontramos a la mañana siguiente, en la tercera secuencia:

Es invierno y Antonio está sentado en su silla de ruedas en el extenso jardín que rodea la casa familiar. Llega la enfermera que le cuida, y le dice que se concentre pues su deber es aprender a escribir su nombre en el papel que tiene frente a él, sirviéndose "sólo de la mano derecha". Después, la enfermera se pone a hojear una revista y entonces el enfermo se distrae y empieza a contemplar los árboles del jardín; luego baja la mirada y la dirige hacia la piscina que está limpiando el jardinero. Todo parece muy tranquilo hasta que, de pronto, Antonio observa algo que le produce extrañamiento: La cámara entonces enfoca hacia el jardín y le vemos a él en su silla de ruedas, avanzando inexorablemente hacia la piscina. Su cara es de angustia y sus manos están ensangrentadas, pero no puede ni parar ni gritar. Cuando llega al borde, el jardinero ya no está allí y él termina cayendo boca abajo dentro de ella.

También en esta secuencia volvemos a encontrarnos con ciertos símbolos que nos remiten al discurso familiar-político-religioso que recorre toda la película, ya que de nuevo aparece la mano derecha como la única que puede utilizar el protagonista para aprender a escribir su nombre, es decir, para recuperar su identidad y volver a ocupar su papel como cabeza de familia. Este discurso dominante se va a ir oponiendo cada vez más a otro segundo discurso, que por oposición se asocia a la izquierda, lo torcido, el pecado y también, como veremos en la próxima secuencia, a los perdedores de la guerra, pues Antonio, al haber salido del orden simbólico al que pertenecía y en el que quiere volver a hacerle entrar la familia, ha pasado a representar contradictoriamente al otro. $^{6}$

Con respecto a esto, Marcel Oms (1981:49-50) relaciona así la sexualidad del protagonista con el discurso político-familiar-religioso presente en El jardín de las delicias:

\footnotetext{
${ }^{6}$ Su parálisis, por otro lado, podría verse como la parálisis de todo un país que a principios de los años 60 intentó introducir una serie de cambios socioeconómicos (a los que se apuntó la familia de Antonio Cano en la ficción), pero que acabaron originando una crisis general, ya que la nueva política incurría en una grave contradic-
} 
En la película de Saura, diversos aspectos de la lujuria, como el "pecado" en la moral católica, manifiestan su fuerza corrosiva ya que la sexualidad del personaje principal es explorada a fondo por todos los miembros de la familia, que presienten que todo el principio de la acumulación capitalista reside en el enigma de la vida sexual de su "amo". Después del ambiente puritano y culpabilizador de la infancia hasta el adulterio compensador de una vida conyugal refrigerante, todos los aspectos de esta vida de trabajo, de beneficios y de ahorro se presentan puntuados por conflictos eróticos asociados a los episodios que marcan la historia de la patria. ${ }^{7}$

Por otro lado, si seguimos ahora la trayectoria de los símbolos que aparecen en esta secuencia y los analizamos a un nivel más profundo y desde el punto de vista de la simbología tradicional, observaremos que se da una concatenación de elementos muy significativa:

En primer lugar está el jardín, y en él los árboles a los que Antonio mira como indicando un deseo inconsciente de querer elevarse. ${ }^{8}$ Este deseo de volar, de ascender para acceder a un nivel superior y poder identificarse con otra realidad, podría asociarse con el expresado por San Gregorio Magno, tal y como nos recuerdan G. de Champeaux y D. S. Sterckx en su Introducción a los símbolos (1984:417):

San Gregorio Magno se expresa acertadamente cuando dice que "por la contemplación, en la que somos levantados sobre nosotros mismos, nos hallamos como elevados en los aires".

ción con los valores e instituciones que mantenían el viejo régimen autoritario. Al no sustentarse en una base democrática porque la estructura político-social seguía siendo la misma que en los años de la guerra, se produjo en un momento determinado el hundimiento de la concepción desarrollista y la parálisis del país.

${ }^{7}$ La cita ha sido traducida por la autora de este artículo.

${ }^{8}$ También en otras películas de Saura los personajes intentan superar su angustia volando imaginariamente en un deseo de liberarse del mundo en el que se encuentran atrapados:

En Ana y los lobos, por ejemplo, hay una escena donde un pájaro artificial revolotea en la ventana de José, el hermano "militar", que le dispara con su pistola haciendo que éste caiga. La escena aparece relacionada con Fernando, otro de los hermanos que pretende ser un asceta y poder levitar, para lo que se encierra en una cueva cercana a la casa familiar.

Después, en Mamá cumple cien años, vemos a este mismo personaje con unas grandes alas intentando inútilmente aprender a volar. Esto es lo que dice Fernando en su laboratorio, que está lleno de planos y aviones en miniatura: "Con qué entusiasmo, ardor y voluntad debo yo emprender la tarea de volar algún día con mis propios medios... Dominar a voluntad mi vuelo... Sin pensar en nada... los ojos semicerrados... encerrado en mi cuerpo emplumado... buscando esa paz que dicen se al canza sólo en las alturas..." (Lista de diálogos, Sec. 28).

En Mamá cumple cien años además, vemos cómo la madre es descendida en su sillón del piso segundo de la casa mediante cuerdas el día de su cumpleaños. Fernando le explica a Ana, otra de las protagonistas, que "bajaba así el día de su cumpleaños... hasta el día en que perdió el virgo" (Lista de diálogos, Sec. 51), acumulando de esta manera toda una serie de elementos iconográficos y simbólicos..

Otra película en la que observamos un deseo de volar es en Cría cuervos, donde Ana, la niña protagonista, está escuchando el canto de los pájaros junto a un gran árbol en el jardín y al mirar al edificio de enfrente se ve a sí misma volando por encima de la ciudad. Terminada la alucinación, Ana baja unas escaleras y entra en un cobertizo que hay junto a la piscina para sacar de un escondite una caja de perborato sódico, que es el "veneno" con el que cree haber matado a su padre. 
Sin embargo, la mirada del personaje no permanece allí sino que desciende a nivel de la tierra para acabar viéndose irremediablemente sumergido en las frías aguas de la piscina, imagen ésta que también podría encontrar una explicación en la simbología tradicional (Champeaux y Sterckx, 1984:423):

El hombre volteado... es un hombre lanzado con los pies al aire y la cabeza y las manos en el suelo, o sea... en posición invertida, cabeza abajo. Al perder la postura recta, ha perdido lo que ésta simboliza y contiene de esfuerzo hacia lo alto, hacia el cielo, hacia lo espiritual. No escala el eje del mundo hacia el polo celeste y hacia Dios, sino que se sumerge en el submundo animal y en las tenebrosas regiones inferiores. En el combate moral consigo mismo y contra su propio pecado... la derrota culpable está señalada por el volteo del vencido.

Antonio además no puede adoptar una postura vertical y ello tiene también un significado importante porque la verticalidad, tal y como nos recuerdan por ejemplo los sermones eclesiásticos, es un signo distintivo del hombre. La representación de éste en posición invertida representa por contrapartida al pecador y es entonces cuando se produce la animalización (Champeaux y Sterckx, 1984:427):

San Bernardo describe el alma encorbada en un cuerpo recto; la escultura románica muestra, a través del cuerpo no solamente encorbado sino invertido, el deplorable estado del alma.

Así pues, en contrapartida con la elevación está la caída, y la de Antonio bien podría asociarse a la del tirano, como la descrita por Isaías, o a la imagen del pecador como la de Simón, ya que antes de su accidente él era un tirano con su familia (que se lo recordará a lo largo de la película) y ha cometido el pecado de adulterio. La caída viene a ser por tanto un elemento que habría que sumar al castigo corporal representado por el cerdo de la primera secuencia. La razón de este segundo castigo sigue siendo el deseo hacia la madre, que aquí aparece representada en la figura de la voluptuosa tía a la que Antonio se imaginó en la segunda secuencia. Y junto a estos dos castigos consecutivos se encuentra, no debemos olvidarlo, un tercer castigo, que es el de la parálisis física y mental del protagonista.

Por último, esta imagen del personaje en posición invertida nos está haciendo recordar a ese otro Jardín de las delicias de El Bosco, donde aparecen varias figuras volteadas y donde, en la parte central, podemos ver a un hombre cabeza abajo dentro del agua sosteniendo entre sus piernas una gran fresa, símbolo de la sexualidad y el erotismo.

\section{Secuencia de la comunión}

Esta secuencia es la número cuatro y puede verse como otra representacion familiar organizada por el padre de Antonio en una especie de nave abandonada. Ahora, el "director de escena" quiere hacerle recordar al hijo el día "más feliz de su vida": la Primera Comu- 
nión. Al iniciarse la secuencia vemos un telón grande y rojo que se va abriendo mientras un coro de niños canta desde lo alto: "Dueño de mi vida, vida de mi Amor, ábreme la herida de tu corazón [...]". Entonces descubrimos a Antonio sentado en el lugar del trono y en una majestuosa silla. Luego, la cámara se vuelve y frente a él aparece, mirándole, un niño desconocido ("Antoñito") vestido con un traje de Comunión y detrás suyo, todo el clan familiar que se ha "disfrazado" con ropas de la época para la ocasión. Un sacerdote entra entonces en la escena y, colocándose frente a "Antoñito" y de espaldas a Antonio, comienza a leer. Pasados unos minutos, el padre se pone al lado de Antonio y le dice que si recuerda ese día, que fue precisamente el 14 de Abril de 1931, año en que se proclamó la Segunda República. Al parecer, cuando estaban en la ceremonia, el "canalla del organista" empezó a tocar el himno y un gran gentío, armando un gran revuelo, irrumpió en la iglesia gritando “iViva la República!". Esto mismo es lo que ocurre en la representación organizada ahora por el padre y a consecuencia de ello Antonio, cada vez más exaltado, logra levantarse por primera vez y superponiendo su propia representación a la familiar, confunde el acontecimiento con el estallido de la Guerra Civil española, mientras grita por primera vez: "La guerra... del 36, la aviación..., ¡Ahhhh!"

Existe en esta rica secuencia una acumulación de fechas familiares, festividades religiosas y acontecimientos políticos que coinciden nuevamente, y no de casualidad.

En lo que se refiere al discurso religioso, hay una crítica velada a la Iglesia católica como institución que seguramente fue lo que vislumbró la censura española a la hora de autorizar la exhibición del filme, pues como dice Miret Jorbá (1976:5), lo que Saura estaba poniendo en tela de juicio con esta ceremonia era:

Un fenómeno absolutamente ritual, reducido a la repetición de unas determinadas convenciones externas sin ninguna relación con la pretendida "espiritualidad" que se les atribuye. Autopunitivo y con marcada tendencia a las "penitencias" físicas de origen ancestral.

La celebración religiosa sirve para rememorar el momento de la proclamación de la Segunda República, con el que curiosamente coincide, y este eje temporal se complica aún más al confundir y superponer Antonio esta fecha con el estallido de la Guerra Civil, cuyo trauma le hace hablar y levantarse de su silla con la mano derecha extendida en lo alto, como indicando un nuevo castigo venido del cielo.

La derecha, asociada de nuevo a la verticalidad, la salvación, lo recto, el orden patriarcal, el bien y también la prohibición, es la que está imponiendo el castigo a la izquierda, que por el contrario indica perdición, distorsión, condena, lo siniestro, la rebelión, los bajos instintos y en última instancia el subconsciente. Pero si bien la derecha política es la que impuso el castigo a la izquierda después de la contienda, Antonio, en su aparente desvarío, está dando aquí cabida a la voz de los perdedores (y a este respecto es muy significativo el que en un momento determinado la cámara subjetiva, que adopta el punto de vista del protagonista, recorra todos los rostros de los invitados mientras al fondo se oye un ruido de metralletas que parece estar aniquilándolos a todos). 
Pero paralelamente a esta crítica consciente hacia los estamentos políticos, familiares y religiosos, existe también una lectura simbólica que sigue marcando una trayectoria de sentido muy cercana de nuevo a la obra de El Bosco y que nos hace volver a encontrarnos con el eje sintagmático marcado por la culpa, el castigo y el perdón:

Después de manifestarse la culpa en el deseo sexual y de haberse producido el castigo con la caída a la piscina, lógicamente cabía esperar el momento de un nuevo perdón, que tiene lugar durante la Comunión, entendida ésta como acto de purificación. A ello nos remiten claramente las palabras que dice el sacerdote en esta secuencia: ${ }^{9}$

Antoñito, mira los árboles y las hierbas del campo y hallarás que ellos producen y echan de sí, flores, hojas y frutos. Las plantas y los árboles producen de sí aceite, vino y bálsamo y echan un olor muy suave. Al final, cual es el árbol, tal es el fruto, porque el árbol malo no puede llevar fruto bueno.Y así el hombre, Antoñito, es un árbol vapuleado por los vientos, y sólo teniendo raíces muy profundas, podrá soportar los huracanes y las tempestades. Y sólo resistiendo las inclemencias del invierno, el calor de los veranos, podrá el árbol alzarse fresco y lozano y dar así dulces y sabrosos frutos $[\ldots]$

Estas palabras son las que, apoyándose en el testimonio de Cristo, pronunció precisamente San Jerónimo, quien, según Morales y Marín (1984:51):

Compara al hombre con un árbol, porque como el árbol, produce buenos y malos frutos, es decir, actos virtuosos o inmorales. Y también - diceque el árbol es el emblema del hombre justo para cuya destrucción no bastan los vientos malos de la vida. Un árbol adornado con hojas significa en general el paraíso o la felicidad eterna.

Continúa así en esta secuencia esa asociación del hombre con el árbol, que significa ascenso, verticalidad e incluso resurrección. La sucesión o concatenación de símbolos se muestra por lo tanto cada vez más clara ya que nos está remitiendo a toda una tradición en la que éstos ya estaban presentes: Por ejemplo, en algunas tumbas de la Antigüedad también pueden verse dos árboles, el de la derecha frondoso y verde y el de la izquierda marchito; y lo mismo observamos en ciertas portadas románicas, donde aparecen: a la izquierda, el pecado original que ha apartado al hombre del árbol de la vida, y Eva pecadora que coge la manzana. A su lado, una figura humana condenada, cabeza abajo y pisoteada por el demonio, que es la imagen del pecador tal y como ha quedado después de la culpa original y tal como

\footnotetext{
${ }^{9}$ En La prima Angélica también el sacerdote usa el tema del árbol para reprender a Luisito, el personaje adulto-

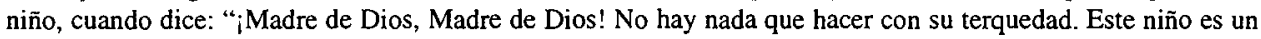
árbol torcido. Educación, eso es lo que necesita. Nada, nada, este niño lo que necesita son unos ejercicios espirituales". (Lista de diálogos, Rollo 7).
} 
cae por su propio pecado. A la derecha está Jesucristo, nuevo árbol de la vida, y cómo salvación a la imagen del pecador volteada también puede verse a un personaje sonriente y pacífico que enarbola un hermoso follaje y coge al desgraciado por los cabellos disponiéndose a liberarle del lugar maldito y a ponerle nuevamente de pie.

\section{Secuencia final}

A lo largo de toda la película se han ido sucediendo las representaciones y los intentos por parte de toda la familia de hacer recuperar a Antonio la memoria: mediante la vuelta a la empresa, enfrentándole a la junta directiva, escenificando la muerte de su madre, llevándole su mujer a dar un romántico y frustrado paseo en barca para revivir el amor perdido e incluso trayendo a la casa a Nicole, la ex-amante del protagonista. Pero al final, nada ha dado resultado porque Antonio, a pesar de haber hecho esfuerzos por hablar y levantarse, ha caído definitivamente y es ya incapaz de volver a ocupar su puesto en el trabajo, en la familia y en la sociedad.

En esta última secuencia, el protagonista aparece nuevamente sentado en su silla de ruedas y en el jardín, donde tiene lugar primero una representación subjetiva que le lleva a contemplarse a sí mismo y a su ex-amante en el momento en que tuvo el accidente de coche. Mientras yace en el suelo con el cuerpo ensangrentado, Antonio repite dos veces: "Mi cabeza. Dios mío, mi cabeza. Que hagan lo que quieran con mi cuerpo, pero que no me toquen la cabeza".

Luego, la cámara vuelve a enfoncar a Antonio, que mueve perfectamente los dedos de la mano izquierda pero sigue sin poder mover los de la derecha, y mientras él sigue mirando el jardín, el espectador puede observar cómo detrás suyo empiezan a desfilar el padre y la actriz/madre sentados, ellos también, en sillas de ruedas.

Entonces se produce un cambio de escenario en el que vemos a Antonio corriendo por la parte trasera de la casa y saliendo al exterior como en un intento de escapar y liberar su espíritu. En ese momento escuchamos su voz en off que dice: "He sido niño, una muchacha, una mata, un pájaro... y un mudo pez que surge del mar".

Por último, en otro cambio de escenario, Antonio aparece de nuevo en el jardín (esta vez sin que se vea ya el coche destrozado del accidente). Es el plano final donde él se ve a sí mismo en el centro y rodeado de todo el clan familiar, que inválidos como él en sillas de ruedas, vagan por el lugar sin rumbo fijo y con el rostro inexpresivo.

Es ésta una secuencia de bastante complejidad en la que se suceden varias representaciones subjetivas por parte de Antonio, que aparece como espectador de su propia tragedia, y como protagonista. A lo largo de ella, oímos dos veces su voz: la primera suplicando que no le toquen la cabeza, aunque pueden hacer lo que quieran con su cuerpo. Este deseo conecta con el hecho de que la mano derecha ha quedado definitivamente inmovilizada, pues de acuerdo con la iconografía cristiana de Occidente dicha mano está relacionada con la identidad y con el funcionamiento de la cabeza y los procesos mentales.

En cuanto a sus últimas palabras, éstas pertenecen a Las purificaciones, el gran poema que sobre la naturaleza escribió el filósofo místico Empédocles de Agrigento, al que ya 
hemos mencionado al hablar del tríptico de El Bosco. Empédocles fue un hombre muy preocupado por la teoría del conocimiento y de la perfección y junto a los cuatro elementos (aire, agua, tierra y fuego) afirmó la existencia de dos fuerzas rectoras: el Amor y el Odio. Sobre Las purificaciones, que es el libro donde plasmó toda su teoría, nos dice J. Bernhardt (1982:51):

En esta obra, más fuertemente impregnada del espíritu órfico-pitagórico, está claro en todo caso que se abre paso a una verdad sobrenatural, promesa de salvación fuera del "ciclo de los nacimientos" y de la transmigración, al margen de este mundo en el que estamos actualmente, y que viene a ser, haciendo más urgente todavía la preocupación de la salvación, el mundo en el que progresa el Odio. Empédocles, como profeta y sabio, se siente precisamente en su última reencarnación. Existe, por tanto, otro mundo, objeto del verdadero conocimiento y morada de la felicidad, de donde ha sido desterrada para castigo suyo la parte inmortal de nosotros mismos. En este mismo mundo hubo una Edad de Oro en la que seguía reinando el Amor, pero el Odio muy pronto impulsó a los hombres a matar y devorar a los animales, es decir, a otros humanos encarnados en ellos.

Son significativas las últimas frases de esta cita porque precisamente el final que Saura había planeado para su película era el de unos perros devorando a los personajes, tal como le confesó a E. Brasó (1974:288)

Sí, no debía ser así. Pero el final actual sí se acerca a esa cosa buscada por mí de establecer una confusión en la que no se sabe muy bien cuál es la realidad en la que está el personaje. O sea, en ese momento en el que este personaje aparece sentado en una silla de ruedas y de repente dice una frase de Empédocles de Agrigento; y no sé muy bien por qué la dice; ahí entra esa parte de caos mental subjetivizado y objetivizado a la vez pero que me resulta fascinante: "He sido niño, una mata, un pájaro y un mudo pez que surge del mar"... El otro final era esto mismo, pero en último término daba un salto todavía superior, o así lo pensaba yo. Era una escena enormemente realista y cruel en la que una jauría de perros se comían a los personajes que estaban en las sillas de ruedas.

Antonio ha revivido pues su último castigo, el del accidente, y en un intento final trata de buscar una salida imaginándose a sí mismo cruzando el umbral de la puerta y huyendo. Pero al no lograrlo, queda irremediablemente atrapado en el determinismo social e histórico que le rodea. 


\section{Conclusiones}

En la película de Saura nos encontramos con un tipo de relato en el que el orden presente es rechazado por parte del protagonista, que al haber quedado paralizado y con la memoria dañada, se siente alienado en él. Esto se plantea en el texto fílmico a dos niveles:

- El primero de ellos se mueve en un plano más dialéctico y nos remite a los discursos familiar, religioso y político de la sociedad patriarcal en la España franquista. Aquí Saura, de manera consciente, opone el individuo a la familia y la nación haciendo que el personaje deje de identificarse al grupo al que pertenecía y dando paso a través de sus contradicciones, a la otra ideología, la de izquierdas, la que no comulga con el orden establecido y la que critica al Estado y a la Iglesia como instituciones defensoras del autocastigo y la abstinencia de los bienes terrenales.

- Pero a un nivel todavía más profundo podemos ver una preocupación de tipo existencial, metafísico y religioso por parte del autor de la película, de la que quizá él no fuera tan consciente. A esta conclusión se llega mediante el análisis de una serie de símbolos que nos permiten vislumbrar, igual que en la obra de El Bosco, la presencia de tres mundos: el inferior, el superior y el terrenal. En este último nivel, que como ya vimos es el centro de la sexualidad pecaminosa y se considera una morada ambivalente que lo mismo conduce a la salvación que a la condenación, encontramos a Antonio Cano. Este personaje ha sufrido un grave accidente que ha paralizado su trayectoria vital, y a consecuencia de ello se ha visto sometido a un exhaustivo análisis familiar, y también personal, que ha venido marcado por la sucesión culpa-castigo-perdón, y que le ha obligado a plantearse la gran contradicción de su naturaleza humana.

La concepción del mundo que parece presentar la película es pues la de un universo caótico donde el conflicto entre los instintos y la esfera moral provocan en el personaje una profunda angustia y un deseo inconsciente de volver a la unidad perdida. Lo que ocurre es que tras la muerte iniciática, que comienza con la separación de la madre y viene simbolizada por las tinieblas y el vientre del monstruo, Antonio Cano, como hombre, ha de experimentar una sucesión de luchas y pruebas a fin de acceder al nacimiento a un modo superior de ser, y esto es algo en lo que fracasa, pues no consigue trascender su dualidad.

Gracias a una lectura simbólica exhaustiva hemos podido ver cómo las dos obras analizadas convergen en muchos aspectos, y esto no es casual ya que en realidad ambos Jardín de las delicias contienen a su vez elementos iniciáticos que ya estaban presentes tanto en la iconografía religiosa como en la alquimia medieval, y una vez entrados en el siglo XX, en el psicoanálisis freudiano, pues como bien señala Juan Atienza (1987:123) :

En ese mundo de los símbolos tradicionales y de los mitos ocultistas, la historia universal del paraíso perdido se plantea como una historia velada de la conciencia cósmica. Habría que bucear en ese pasado-que en realidad subsiste en lo más hondo de nuestra mente, sin tiempo-, para calibrar hasta qué punto los seres humanos, por medio de su memoria colectiva, como los miembros de una inmensa colmena, no estarán trabajando sin 
saberlo en la conservación o por el renacer de esa Edad de oro perdida en el agujero negro de otra dimensión.

Lo que ocurre es que en la actualidad, una vez perdido su valor ritual, muchos temas iniciáticos se han convertido en esquemas y por ello han decantado su mensaje espiritual en otro plano de la experiencia humana, dirigiéndose directamente a la imaginación y al arte. Sin embargo, no podíamos estar más de acuerdo con Mircea Eliade (1975:212), cuando en sus Iniciaciones místicas llegó a afirmar que:

Por lo que se refiere a los elementos iniciáticos, todavía transparecen, junto a otras estructuras de la experiencia religiosa, en la vida imaginaria y onírica del hombre moderno. Pero también se dejan entrever en ciertos tipos de pruebas reales que afronta el hombre actual en las crisis espirituales, en la soledad y en la desesperación por la que todo ser humano ha de atravesar para acceder a una vida responsable, auténtica y creadora. $Y$ aún cuando el carácter iniciático de las pruebas no se aprecia como tal, no por ello deja de ser verdad que el hombre únicamente llega a ser él mismo... tras haber sufrido "las torturas" y la "muerte" a las que se sigue el despertar a otra vida, cualitativamente distinta al estar "regenerada".

\section{Bibliografía}

ATIEnZA, J. (1987) Claves ocultas de la historia, Barcelona: Obelisco.

BERNHARDT, J. (1982) Historia de la filosofia; ideas y doctrinas, Vol. I, Madrid: Espasa Calpe.

Brasó, E. (1974) Carlos Saura, Madrid: Taller de Ediciones J. B.

ChAMPEAUX, G. y D. S. STERCKX (1984) Introducción a los símbolos, Vol. 7, Madrid: Encuentro.

Chevalier, J. y A. Gheerbrant (1986) Diccionario de los símbolos, Barcelona: Herder.

CoHn, B. (1977): "Entretien avec Carlos Saura" en Positif, Num. 174, pags 27-33.

ELIADE, M. (1975) Iniciaciones místicas, Madrid: Taurus.

FuCHS, E. (1996) Historia ilustrada de la moral sexual: 1. Renacimiento, Madrid: Alianza Editorial.

Gauffreteau-Sevy, M. (1967) Hieronymus Bosch, "El Bosco", Barcelona: Labor. HidALGo, M. (1981) Carlos Saura, Madrid: Ediciones J. B.

Miret JorbÁ, R. (1976) "Carlos Saura”, en Dirigido por, Num. 36, pags 1-11.

MoRAles y MARín, J. L. (1984) Diccionario de iconología y simbología, Madrid: Taurus. OMs, M. (1981) Carlos Saura, París: Cinématographique, Ligue Française de l'Enseignement.

PERADEJORDI, J. (1991) El cuerpo humano, Barcelona: Obelisco. 


\section{ČLOVEŠKO TELO KOT SIMBOL V VRTU UŽITKOV: TRIPTIH HIERONIMA BOSCHA IN FILM CARLOSA SAURE}

Gre za globinsko primerjavo 400 let starega Boschevega triptiha "Vrt užitkov" iz Prada z istoimenskim filmom Carlosa Saure iz leta 1969. Na desnem krilu grotesknega triptiha je ponazorjena stvaritev sveta, na levem pekel, kjer hudič čisti čreva grešnikov, obsojenih na večni ogenj, v osrednjem delu pa vidimo številna človeška gola telesa $\mathrm{v}$ različnih erotičnih držah, nekatera $\mathrm{z}$ glavo navzdol ali spremenjena $\mathrm{v}$ ptice ali ribe - prava slika grešne seksualnosti.

Film Vrt užitkov prikazuje zgodbo Antonia Cana, moža kakih štiridesetih let, ki skupaj z ljubico doživi prometno nesrečo in $v$ njej izgubi spomin: je paraliziran in obsojen na invalidski voziček. Njegova buržoazna katoliška desničarska družina iz Madrida skuša skozi vrsto asociacij, dogodkov in oseb prebuditi Antoniev spomin na preteklost, še zlasti na podatke, pomembne za družinsko podjetje. Toda v Antoniu to sproži spomine na cele prizore iz travmatičnega otroštva $z$ začetkov Francove Španije, ki so vsaj toliko dekadentni in senzualno pogubni kot Boschev triptih. Človekova uživalska sla se namreč kaznuje že na tem svetu.

Degradirano človeško telo je najbolj oprijemljiv simbol razvratnega življenja. Saura sam je v pogovoru izjavil, da je Španija kot vrt užitkov, poln malih spak, v katerem je vse mogoče. 